\title{
Decay dynamic of coarse and fine woody debris of a beech (Fagus sylvatica L.) forest in Central Germany
}

\author{
S. Müller-Using $\cdot$ N. Bartsch
}

Received: 20 May 2007/Revised: 25 January 2009/Accepted: 30 January 2009/Published online: 21 February 2009

(C) Springer-Verlag 2009

\begin{abstract}
Decay rates of woody debris were estimated and used to model the decay of various diameters of branches and stems in a beech stand in Central Germany. In addition, use of wood density, volume and mass loss to quantitatively describe the degree of decay was tested. The mass loss during decay could be described by a simple exponential function. Under the presented climatic conditions, beech coarse woody debris (CWD) with a diameter $>10 \mathrm{~cm}$ decays completely in about 35 years. In the first 8 years of decay the mass loss is determined by the decrease in wood density, and subsequently by the loss in volume. Estimation of wood density allows the first three of the four classes of decay to be distinguished, while trees in the last two decay classes could be distinguished using wood volume. Beech fine woody debris with a diameter between 1 and $10 \mathrm{~cm}$ decays within about 18 years. The litter fraction of $<1 \mathrm{~cm}$ is part of the humus layer after 4 years. If there are goals for the amounts, types and dimensions of woody debris to be provided for conservation of biological biodiversity and other ecological functions in managed beech forests, this study offer indications for how long existing woody debris can meet its functions and how frequent new input of CWD is required.
\end{abstract}

Communicated by J. Bauhus.

S. Müller-Using

Instituto Forestal, Fundo Teja Norte $\mathrm{s} / \mathrm{n}$,

Cassilla, 385 Valdivia, Chile

N. Bartsch $(\square)$

Department of Silviculture and Forest Ecology of the Temperate

Zones, Georg-August-University Göttingen, Büsgenweg 1,

37077 Göttingen, Germany

e-mail: n.bartsch@forst.uni-goettingen.de
Keywords Deadwood - Decomposition · Wood density · Forest dynamics - Chronosequence

\section{Introduction}

The decomposition of woody debris has an important influence on carbon (C) retention in forest ecosystems (Yatskov et al. 2003). Woody debris is also an important long-term nutrient storage (Harmon et al. 1986) and is widely regarded as an important structural element for the provision of biodiversity (Christensen et al. 2005). Low levels of woody debris are considered to be a major factor causing the decrease in biodiversity in European forests (Schuck et al. 2004; Christensen et al. 2005; Assmann et al. 2007; Böhl and Brändli 2007; von Oheimb et al. 2007). The amount of woody debris is normally much lower in managed forests than in unmanaged old-growth forests: most of the large-sized harvestable timber is extracted from managed forests. The remaining trees produce woody debris consisting of twigs and branches (Christensen et al. 2005). In Germany, branches and twigs have not been used as fire wood for several decades. As a result, fine woody debris (FWD) is readily available in most forests (Röhrig 1991). However, the high number of endangered species of saproxylic fauna (Berg et al. 1995; Binot et al. 1998; Ranius and Fahrig 2006; Franc et al. 2007) requiring woody debris to survive, suggests that the availability of coarse woody debris (CWD) in managed forests is insufficient.

A certain level of CWD storage is a requirement for close-to-nature forest management (Pommerening and Murphy 2004) and certification (FSC 2008; PEFC 2008) of forests. Timber harvesting forests should function as links in a woody debris habitat network (Scherzinger 1996; Ammer and Utschick 2004). However, management 
concepts to achieve goals for European forests have not yet been developed, because the factors influencing the quantity, quality, and dynamics of woody debris are not sufficiently identified. Therefore, Current models for CWD dynamics in Europe (Rademacher and Winter 2003 for beech; Ranius et al. 2003 for spruce) cannot be widely applied.

Because beech forests are widespread and represent the potential natural vegetation of many areas in Central Europe (Czajkowski et al. 2006; Bolte et al. 2007), information about the decay dynamic are of particular interest for these forests. Data on the volume of woody debris in 86 beech forest reserves, covering most of the range of European beech forests, were analysed by Christensen et al. (2005). The mean volume was $130 \mathrm{~m}^{3} \mathrm{ha}^{-1}$ and the variation among reserves was high, ranging from almost nil to $550 \mathrm{~m}^{3} \mathrm{ha}^{-1}$. The amount of woody debris is 10-20 times higher in unmanaged than in intensively-managed production forests. The study by Christensen et al. (2005) offers an indication of what guidelines for a sustainable woody debris management might include, but it also demonstrates the limited basic knowledge on decay dynamics of beech woody debris.

In Central Germany, an experimental site in an oldgrowth beech stand was established in 1998. The CWD stores at the experimental site over a 14-year period have been published by Müller-Using and Bartsch (2003). In the paper presented here, the decay dynamics are presented in terms of wood density, volume, and mass using a chronosequence approach. It has been demonstrated for tree species in North America, south Argentina, the boreal zone of Europe, and in the tropics of the central Amazon, that the decay rate of CWD is determined largely by the diameter of woody debris (Harmon et al. 1987; Edmonds and Eglitis 1989; Marra and Edmonds 1996; Frangi et al. 1997; Chambers et al. 2000). Hence, in this study decay rates of twigs (diameter $<1 \mathrm{~cm}$ ), branches (diameter $1-$ $10 \mathrm{~cm}$ ), and CWD (diameter $>10 \mathrm{~cm}$ ) were determined. The objectives of this study were (1) to characterize the decay stages by physical parameters, (2) to predict the residence time based on wood density, and (3) to determine the residence time in the decay classes.

\section{Materials and methods}

\section{Study site}

The study site is located in the Solling, a hilly landscape in the centre of Germany, at an altitude of $500 \mathrm{~m}$ a.s.l. The climate is humid with an average annual temperature of $7.0^{\circ} \mathrm{C}$ and an average annual precipitation of $1,032 \mathrm{~mm}$. The soil is a podsolic brown earth, poor in base cations, which developed from sandstone covered with an 80-cm deep loess layer. The site is classified as a Luzulo-Fagetum typicum (Ellenberg et al. 1986; Bartsch et al. 2002).

The study site borders on the beech stand B1, which has been investigated since 1966 as part of the International Biological Program (Ellenberg et al. 1986). In the 160year-old beech forest of the study site, which developed from natural regeneration, forestry operations such as thinning and harvesting have not been carried out since 1967. In 2002, the standing volume of the living trees was $497 \mathrm{~m}^{3} \mathrm{ha}^{-1}$, and the woody debris volume was $72.9 \mathrm{~m}^{3} \mathrm{ha}^{-1}$ (Müller-Using and Bartsch 2003). The 8 ha experimental site was fenced in 1989 and divided into a $10 \mathrm{~m} \times 10 \mathrm{~m}$ grid cells to assist spatial analysis. The dynamics of vegetation and element budgets of forest gaps have been studied since 1990 (Bartsch 2000; Bartsch et al. 2002; Bauhus et al. 2004).

Methods

In 1990, 1994, 1998, and 2000 CWD (diameter $>10 \mathrm{~cm}$ ) was mapped and the decay classes were determined. In 2000 FWD (diameter $<1 \mathrm{~cm}=$ twigs, diameter $1-$ $10 \mathrm{~cm}=$ branches) was also assessed. In 2002 and 2003, newly added FWD and CWD was mapped and measured. An extensive inventory of CWD based on the method developed by the Lower Saxony Forestry Research Institute (Meyer 1999) was carried out in conjunction with the sectional measurement of dead trees including their crowns in each grid cell (Pillsbury and Reimer 1997). Here diameter on both ends and the height or length of the woody debris pieces were determined. We differentiated between standing woody debris (standing or hanging with a height of over $1.3 \mathrm{~m}$ ) and fallen woody debris (fallen wood and stumps). The amount of FWD that had fallen from the crowns of dead lying trees was sampled in squares $\left(0.25 \mathrm{~m}^{2}\right)$ in three areas underneath the crown $(1 / 4,1 / 2$, and $3 / 4$ crown length). Depending on the size of the crown, the FWD was collected from 3 to 6 sample quadrates and the volume was determined. On crowns with a projected area of $<30,30-50,50-70$, and $>70 \mathrm{~m}^{2}, 3,4,5$, and 6 quadrates respectively were placed under the upper, middle, and lower crown. The volume of FWD outside the projected crown area of dead trees was sampled in $0.25 \mathrm{~m}^{2}$ quadrates in a $30 \mathrm{~m} \times 30 \mathrm{~m}$ grid across the entire area of the site. The difference between the average volume of FWD on the forest floor and that determined under the crown of a dead tree was assumed to be fallen from the crown of the respectively dead tree and included in its volume calculation.

The residence time of the woody debris from 1990 onwards was estimated using repeated assessments. Evidence for back dating the mortality of stems fallen 

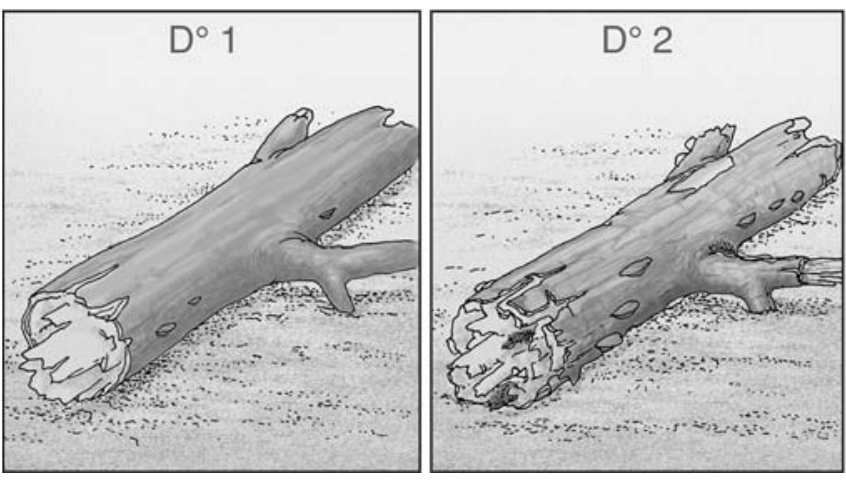

Fig. 1 Decay classes (D 1-4) for laying coarse woody debris (after Müller-Using and Bartsch, 2003). D1 recently dead, cambium still green, crown intact. D2 bork sloughing, fine longitudinal shakes in

before 1990 was obtained from mapping of the damage resulting from storms in 1972 and 1976. The principle wind direction was south westerly, and trees in an advanced stage of decomposition that had fallen in this direction were assigned to these storms. As we did not count with more specific data the mean residence time of the trees was estimated to be 28 years.

The decay class of the woody debris was determined using a four-stage decay class system for beech wood which was developed in this study (Fig. 1). To prove the discriminatory power of the decay classes, the condition of woody debris stems with differing residence time was investigated in more detail.

To form a chronosequence, 30 dead trees, 5 of each age $(0,2,4,8,12$, and 28 years), were selected for sampling. The selected trees fulfilled the following criteria: (1) before death they were dominant trees. (2) The stems could be classed in the decay class 1 (defined as freshly dead, cambium still green, intact crown) when first assessed. (3) The trees had fallen due to breakage of the stem after infection with Fomes fomentarius, or due to damage from the 1970s storm-damaged trees. (4) The stem breaking point was in the lower half of the trunk height. (5) With the exception of the breaking point, the stem had remained intact. These criteria where used because this was the condition of the great majority of dead trees.

A tree fitting the criteria of decay class 1 would have died $<1$ year before being assessed. The other four criteria ensured that the stems were comparable and representative of most of the dead stems within the experimental area.

The stems were sampled in 2002. To determine wood density, 5-cm-thick disks were cut from the stem base, midstem, crown base, and mid-crown areas of the stem. From these disks a 5-cm-wide radial block was cut. Each radial block incorporated the whole stem diameter, vertical to the position of the tree, and passed through the middle of the stem. The radial block was cut into ten smaller blocks of
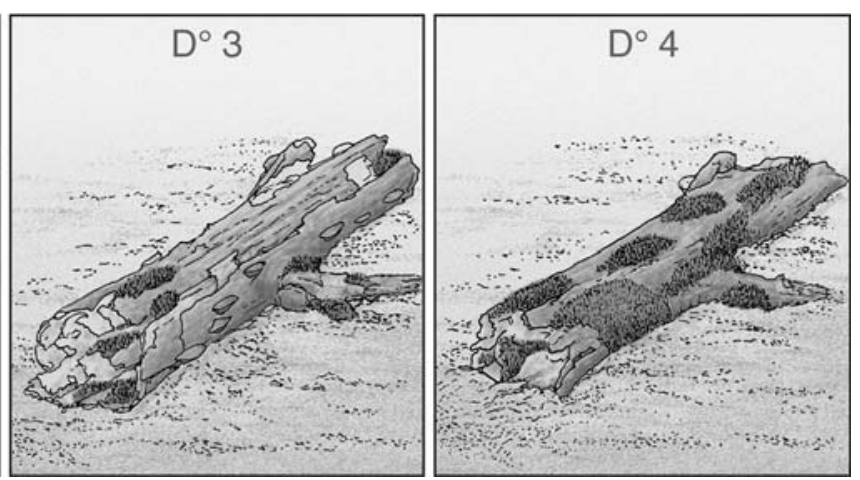

wood, twigs sloping. D3 spreading of the longitudinal shakes to furrows, diameter of present branches $>5 \mathrm{~cm}$. D4 log collapsing, wood friable, crown completely decomposed

the same size, and the bark was removed from each end. Five-cm-disks were cut from branches (diameter 1-10 cm) from 3 positions in the crown. A representative mixed sample was collected for twigs from each crown. To determine the dry wood density the samples were measured with a calliper (mm) and dried at $105^{\circ} \mathrm{C}$ to a constant weight.

Decomposition of the twigs was determined using in situ litterbags (Bocock 1964). In May 2001 the bags were filled with fresh twig material and with up to 2-year-old dead twigs and placed in the $\mathrm{L}$ and $\mathrm{F}$ humus layer. The bags $(20 \mathrm{~cm} \times 10 \mathrm{~cm})$ consisted of $1.8 \mathrm{~mm}$ nylon mesh (detailed method in Bauhus 1994; Bauhus et al. 2004), and therefore should allow access to the mesofauna and a large part of the saprophage mesofauna, as well as the most important litter decomposer, larvae of diptera (Schaefer and Schauermann 1990). Ten grams of air-dried twigs were placed in each mesh bag. A total of 160 mesh bags were placed on a $10 \mathrm{~m} \times 10 \mathrm{~m}$ area. After $3,6,12$, and 24 months, 5 bags per treatment were recovered and the mass loss determined. The density was determined before the bags were installed and after the last recovery.

\section{Data analysis}

To determine the volume loss, the initial volume of trees was estimated. The initial volume (Table 1) was calculated by using diameter at breast height (DBH) of the living trees measured at earlier inventories and by using a linear

Table 1 Linear relationship between diameter $(\mathrm{DBH})$ and volume $(V)$ in woody debris fractions

\begin{tabular}{lll}
\hline Fraction & Function & $R^{2}$ \\
\hline Diameter $<1 \mathrm{~cm}$ & $V=0.0059 \mathrm{DBH}-0.1500$ & 0.97 \\
Diameter $1-10 \mathrm{~cm}$ & $V=0.0324 \mathrm{DBH}-0.9039$ & 0.95 \\
Diameter $>10 \mathrm{~cm}$ & $V=0.1105 \mathrm{DBH}-2.8995$ & 0.96 \\
\hline
\end{tabular}


regression for DBH to volume ratio that was determined from data of a beech stand at a similar site in the Solling (Rademacher 2002) in combination with data of the study site. The trunk form function of Sloboda was used to determine the volume of standing woody debris (Nagel 1999). The parameters used for the calculation were DBH, stump, and tree height. Wood dry density was calculated from dry weight and dry volume. The time $(t)$ a tree took to pass through each decay class (d) was calculated from the mean residence time $(m)$ in each decay class using the equation developed by Ranius et al. (2003):

$t_{d}=2\left(m-\sum_{k=1}^{d-1} t_{k}\right)$

Various functions have been used to describe the decay of woody debris (Harmon et al. 2000; Mackensen et al. 2003). This is often a single exponential function as used to describe the decay of leaf litter (Jenny et al. 1949; Means et al. 1985; Harmon et al. 1986; Harmon et al. 2000).

If an exponential decay is assumed, then the decay constant $(k)$ results in a decay rate per year of:

$k=\frac{\ln \left(x_{0}\right)-\ln \left(x_{t}\right)}{t}$

where $x_{0}=$ initial mass, $x_{t}=$ mass at time $\mathrm{t}, k=$ decay constant, $t=$ time since death (years).

The time required to decay 95 of the original mass $\left(t_{95}\right)$ can be calculated from the decay rate:

$t_{95}=-\ln \frac{(0.05)}{k}=\frac{3}{k}$

Statistical analysis of the data ( $t$ test, median-test) was carried out using the software package Statistica (StatSoft Inc. 2000, Tulska, OK, USA). The $P$ value was employed for the fitting of the decay functions. Significance of differences of density and volume in the different decay phases was tested by a median-test. This test was selected because of the small number of trees sampled in the chronosequence.

\section{Results}

The decrease in volume as a result of decay is presented as a function of the initial volume (Table 2). The parameter used, density or volume, is dependent upon the objective of the investigation. If mass or element storage is to be determined, then an estimate of woody debris mass is required. For management of woody debris, volume data are normally available from stand inventories. An estimation of volume loss of woody debris thus has practical applications. However estimates of short term changes can only be carried out using density.

A significant decline in wood density of CWD occurred between decay classes 1-3. In FWD the difference in wood density in the first two decay classes was significant (Table 2). Wood volume in CWD only decreased significantly from the 3rd to the 4th decay class. For FWD, significant differences were found in the decrease in volume in all decay classes. In CWD, the transition time of each decay class increased as decay progressed (Table 3), and decay class 4 takes almost half of the total transition time.

The mass loss over the complete decay period was calculated from the chronosequence data in relation to the initial mass (Fig. 2). Both data sets show a good fit to an exponential function. The functions describing the percentage mass loss are shown in Table 4.

The annual rate of decay is given by the decay constant $k$ in the exponential decay equation. This equation can be used to estimate the time during which a particular proportion of woody debris decays. The calculated time of decay is similar to the value calculated from the mean transition time of logs in each decay class (Table 3). The decay rate constants do not change greatly as decay progresses (Fig. 3), and only decreases slightly in the final decay phases. The unchanged decay rate constant is further evidence for the applicability of exponential rate of mass loss.

The loss of wood density and volume cannot be described with a simple exponential function, as can be

Table 2 Density $\left(\mathrm{g} \mathrm{cm}^{-3}\right)$ and percent of initial volume of the 4 phases of decay (DC, see Fig. 1) of beech woody debris from stems and crowns

\begin{tabular}{|c|c|c|c|c|c|c|c|c|}
\hline \multicolumn{5}{|c|}{ CWD } & \multicolumn{4}{|l|}{ FWD } \\
\hline \multirow[t]{2}{*}{$\mathrm{DC}$} & \multicolumn{2}{|c|}{ Density $\left(\mathrm{g} \mathrm{cm}^{-3}\right)$} & \multicolumn{2}{|c|}{ Volume (\%) } & \multicolumn{2}{|c|}{ Density $\left(\mathrm{g} \mathrm{cm}^{-3}\right)$} & \multicolumn{2}{|c|}{ Volume (\%) } \\
\hline & Mean & SD & Mean & $\mathrm{SD}$ & Mean & SD & Mean & SD \\
\hline 1 & $0.58^{\mathrm{a}}(30)$ & 0.07 & $100^{\mathrm{a}}(10)$ & 6.4 & $0.57^{\mathrm{a}}(10)$ & 0.06 & $98^{\mathrm{a}}(9)$ & 15.6 \\
\hline 2 & $0.37^{\mathrm{b}}(37)$ & 0.16 & $95^{\mathrm{ab}}(12)$ & 15.4 & $0.40^{\mathrm{b}}(12)$ & 0.09 & $53^{\mathrm{b}}(12)$ & 28.9 \\
\hline 3 & $0.21^{\mathrm{c}}(8)$ & 0.07 & $84^{\mathrm{b}}(10)$ & 21.2 & $0.45^{\mathrm{b}}(3)$ & 0.12 & $19^{\mathrm{c}}(9)$ & 18.2 \\
\hline 4 & $0.26^{\mathrm{c}}(8)$ & 0.17 & $27^{\mathrm{c}}(5)$ & 19.8 & - & - & $0^{\mathrm{d}}(5)$ & 0.3 \\
\hline
\end{tabular}

The number of samples $(n)$ is given in brackets. Mean values not followed by similar indices within a fraction are significantly different (mediantest, $P<0.01$ )

$S D$ standard deviation 
Table 3 Average time required for CWD to pass through each decay class (see Fig. 1, calculation based on Ranius et al. 2004)
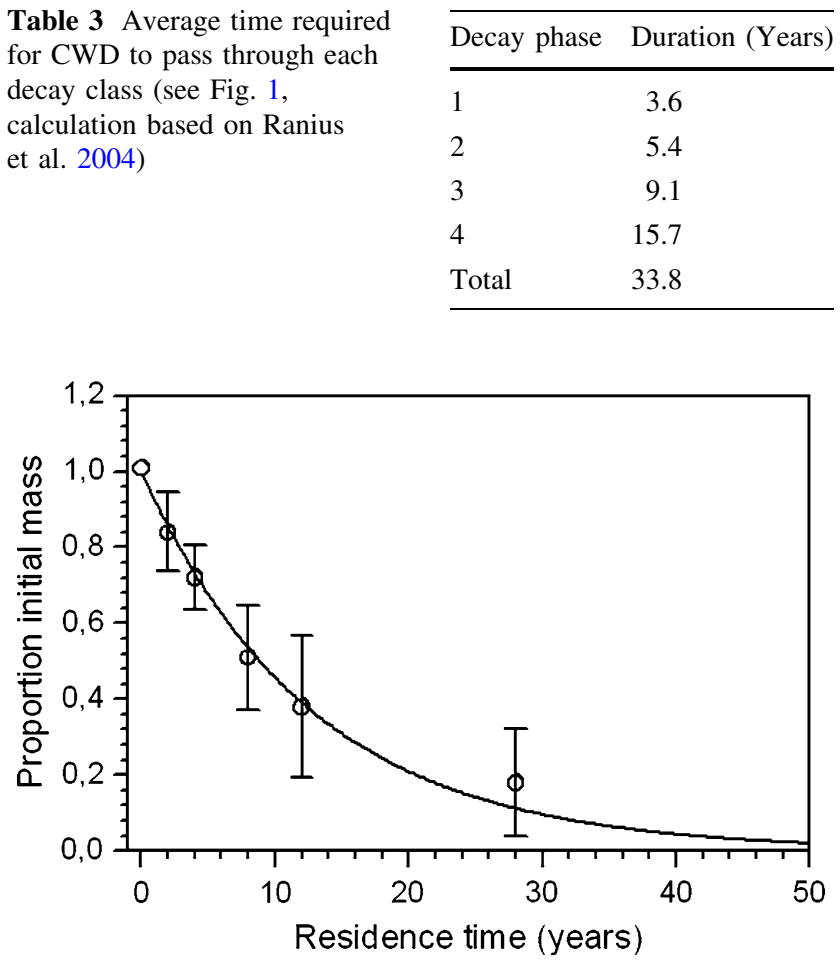

Fig. 2 Percentage mean loss of coarse woody debris during decay based on the initial mass $\left(y=\mathrm{e}^{-0.09 x}\right)$. Bars show the standard deviation

Table 4 Trend fitting, decay constants, and time required for $95 \%$ mass loss of wood and bark of coarse woody debris (diameter $>10 \mathrm{~cm} ; n=30$ )

\begin{tabular}{llllll}
\hline & Function & $r^{2}$ & $P$ & $k$ & $t_{95}$ \\
\hline Wood & $X=\mathrm{e}^{-k t}$ & 0.98 & 0.0002 & 0.089 & 33.8 \\
Bark & $X=\mathrm{e}^{-k t}$ & 0.90 & 0.0053 & 0.109 & 27.5
\end{tabular}

$X$ percentage mass remaining (\%), $t$ time (years), $k$ decay constant, $r^{2}$ goodness of fit, $P$ significance level of the regression ( $t$-test), $t_{95}$ time required for $95 \%$ mass loss (years)

seen clearly in the change of decay constants during transition residence times (Fig. 3b, c). The density decreased directly after the death of the tree, and this trend increased for the first 8 years. The decrease in the decay constant as decay advanced shows that the decrease in density stagnated at this point (Fig. 4).

The low value of the decay rate of CWD for the first 12 years shows that the decrease in volume begins very slowly. The increase in the value of the decay constant over time indicates a linear decay.

The mass loss function as a product of the density and volume loss functions is shown in Fig. 4. If this is compared to the mass-function in Fig. 2, the similarity suggests that the chosen functions are plausible. The mass loss in the first 4 years of decay is primarily due to the decrease in density. The decrease in volume began at this point. After
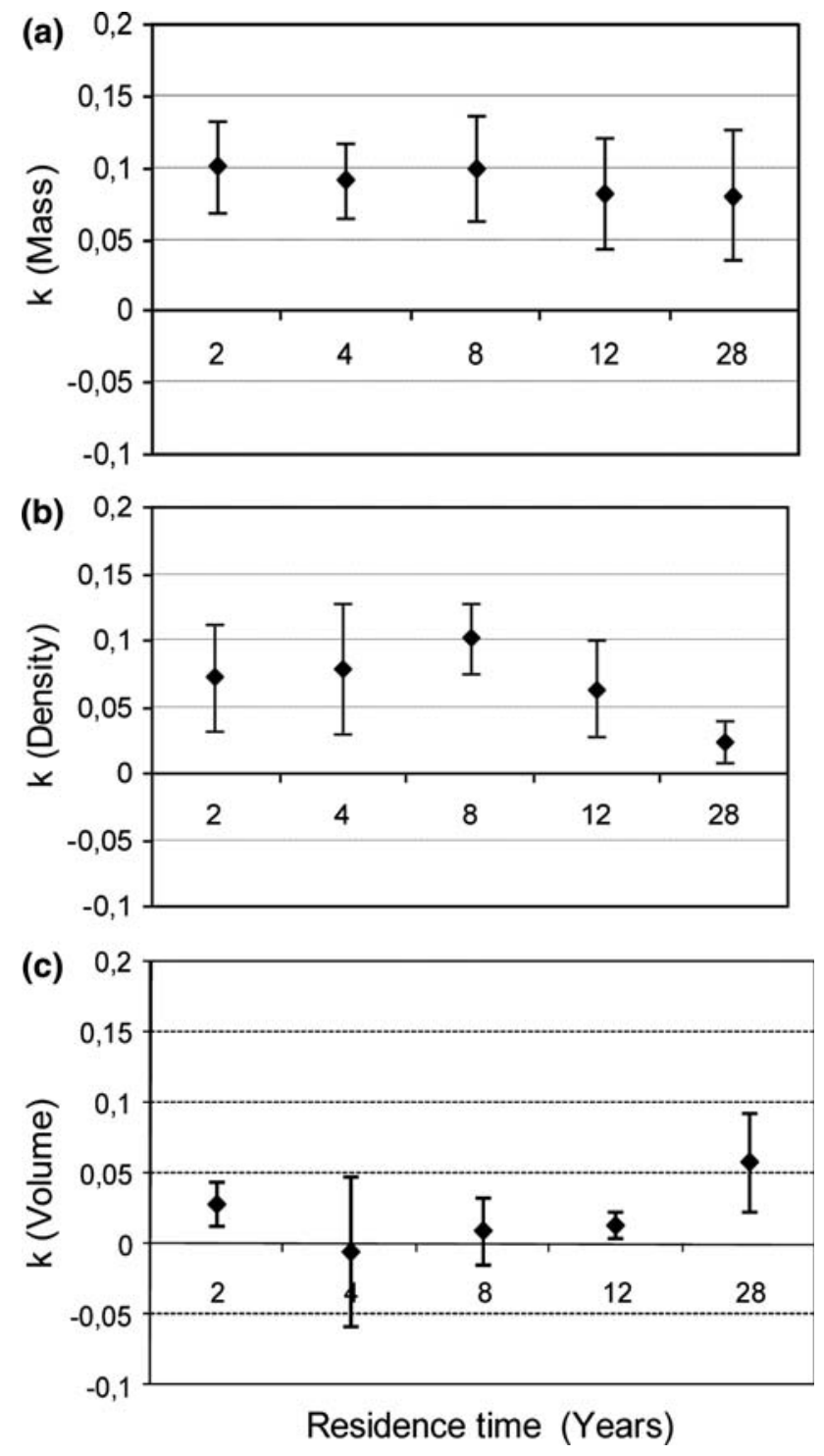

Fig. 3 Mean decay constants $(k)$ for a coarse woody debris mass, b density, and c volume during different durations. Bars show the standard deviation

8 years the density remained at about $40 \%$ of the initial value and did not decrease further as decay progressed.

Branches (diameter 1-10 cm) decayed twice as fast as CWD. After 17 years, $95 \%$ of the FWD mass was decayed (Fig. 5; Table 5), and the bark decayed in half this time. The pattern of decay was similar to that of CWD. As decay progressed, twigs (diameter $<1 \mathrm{~cm}$ ) became more difficult to find on the forest floor and more difficult to associate to specific dead trees. A rapid mass loss in the twigs was determined using mapping, but in litterbags this was only shown in the first phases of decay. At the point where 50\% mass loss was reached in the litter bags, only a small fraction of the twigs could be found using mapping. In the litterbags the mass loss was very slow after 2 years 


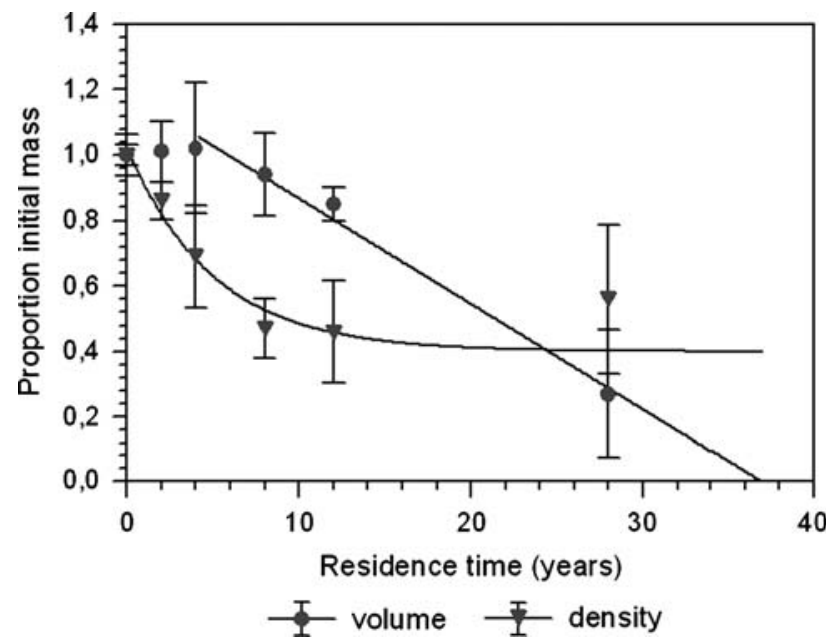

Fig. 4 Decrease of density and volume of coarse woody debris during decay. Mean values and standard deviation (bars) are shown. The functions are Density $=0.4+\mathrm{e}^{-0.26(x+2.39)}$; Volume $=1.15-$ $0.03 x$

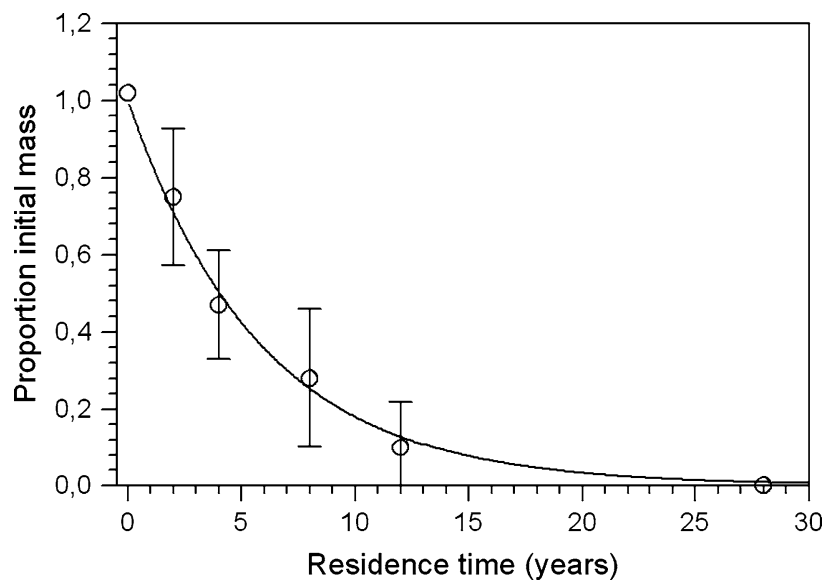

Fig. 5 Percentage mean of initial mass of branches during decay $\left(y=\mathrm{e}^{-0.18 x}\right)$. Mean values and standard deviation (bars) are shown

(Fig. 6). The complete decay of the twigs required a quarter of the time compared to branches (Table 6). This means that mass in the twigs decreased rapidly at the start of the decay class 2 of the trees to which they belong. Trees that had been decaying for 8 years still had twigs attached to the crowns, suggesting that decay of attached twigs processes more slowly, and similar to the twigs in the litterbags, incorporation into the soil is delayed.

\section{Discussion}

Components of the decay process

Because the loss of woody debris via surface water can be eliminated at the research area, the only way in forests
Table 5 Trend fitting, decay constants, and time required for $95 \%$ mass loss of wood and bark of branch (diameter $1-10 \mathrm{~cm} ; n=30$ )

\begin{tabular}{lllllr}
\hline & Function & $r^{2}$ & $P$ & $k$ & $t_{95}$ \\
\hline Wood & $X=\mathrm{e}^{-k t}$ & 0.99 & 0.0004 & 0.178 & 17.5 \\
Bark & $X=\mathrm{e}^{-k t}$ & 0.98 & 0.0008 & 0.350 & 8.6 \\
\hline
\end{tabular}

$X$ percentage mass remaining (\%), $t$ time (years), $k$ decay constant, $r^{2}$ goodness of fit, $P$ significance level ( $t$-test) of the regression, $t_{95}$ time required for $95 \%$ mass loss (years)

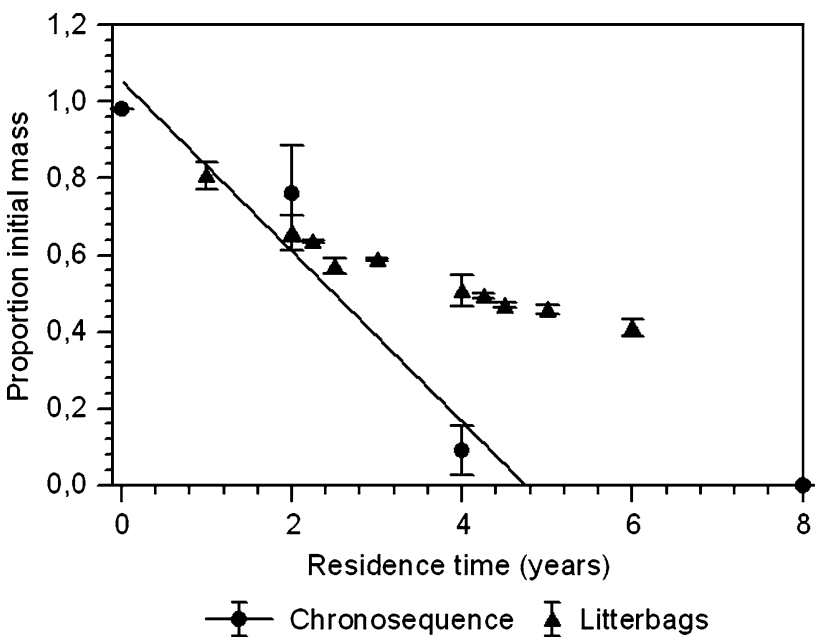

Fig. 6 Mean mass loss of twigs during decay with the function $(y=1.06-0.22 x)$ as percentage initial mass of single trees and litterbags. Mean values and standard deviation (bars) are shown

Table 6 Trend fitting, decay constants, and time required for 95\% mass loss of wood and bark of twigs (diameter $<1 \mathrm{~cm} ; n=30$ )

\begin{tabular}{lllllll}
\hline & Function & $r^{2}$ & $P$ & $k$ & $a$ & $t_{95}$ \\
\hline Wood & $X=a-k t$ & 0.92 & 0.09 & 0.22 & 1.06 & 4.5 \\
Bark & $X=a-k t$ & 0.95 & 0.07 & 0.18 & 0.81 & 4.3
\end{tabular}

$X$ percentage mass remaining (\%), $t$ time (years), $k$ decay constant, $r^{2}$ goodness of fit, $P$ significance level ( $t$-test) of the regression, $t_{95}$ time required for $95 \%$ mass loss (years)

where no wood is removed woody debris stores can decrease is via decomposition (Maser et al. 1988). The mechanisms of decay, respiration, leaching, and fragmentation result in a mass loss which can be quantified using volume and weight. Determination of mass loss is the most common method used to investigate decay processes (Christensen 1977; Grier 1978; Sollins 1982; Harmon et al. 1987; Arthur and Fahey 1990; Arthur et al. 1993; Mackensen et al. 2003). Wood density has also been used to describe decay processes (Arthur et al. 1993; Schwarze et al. 1999; Schäfer 2002), as it is easy to determine and the initial values within a species do not vary greatly (Sollins et al. 1987; Frangi et al. 1997; Mackensen et al. 2003). 
Christensen (1984) showed a direct relationship between mass loss and relative density. A prerequisite for this is that mass loss is only due to leaching and biochemical decay. The patterns of density and volume loss indicate however, that in the decay of beech CWD, fragmentation is not a negligible process. As the presented functions show, mean density decreases only in the first 12 years of decomposition while volume loss continues linear during the whole decomposition process. Additionally studies of leaching (Kuehne et al. 2008) and $\mathrm{CO}_{2}$-emision (Müller-Using and Bartsch 2008) of the same logs showed a difference between carbon loss by this processes and that calculated by mass loss of CWD.

In coniferous forests in Oregon fragmentation has been reported to account for half of the mass loss (Harmon and Hua 1991), usually the part of fragmentation seems about $30 \%$ for this type of climate (MacMillan 1988; Harmon and Hua 1991). Harmon et al. (2000) concluded in a comparative study of the decay rate constants of mass, volume and density of pine, spruce, and birch woody debris in northwestern Russia that the mass decreases more strongly than the density. The change in density due to disintegration of the stem was not taken into account in these studies (Laiho and Prescott 2004), and thus fragmentation was underestimated. The fragmented mass was not included in the estimation of woody debris storage, because the fragmented pieces could not be found and were amalgamated into the humus layer. The smaller the dimension of woody debris, the earlier the process occurred. Hövemeyer and Schauermann (2003) observed in a litterbag investigation of the decay of FWD (diameter $4.3-11.5 \mathrm{~cm}$ ) in a calcareous beech stand (Göttingen Forest, Lower Saxony), that after 2 years $40 \%$, and after 6 years $60 \%$ of the wood was under the litter layer. Again, it was concluded that the smaller the diameter of wood, the higher the rate at which it was covered. Although a direct effect of coverage on the loss of wood density over a period of 10 years could not be shown, an effect was seen on the wood moisture and $\mathrm{N}$ contents. Over the 10-year experimental period, a greater loss of wood density was found than that shown in the study presented here. The loss shown was similar to that of twigs in the litterbag experiment.

Bioturbation increases the rate of mass loss, and is very important in litter decomposition. Mund (2004) determined that in unmanaged beech forests which belonged to the sub-formation Galio odorati-Fagenion $37 \%$ of the annual litterfall was on average incorporated into the soil via bioturbation. Although in beech woods in the Solling, mesofauna species and a large proportion of the saprophage macrofauna such as Diptera larvae and Lumbricidae (Scheu and Falca 2000) could pass through the mesh and access the substrate, mass loss is still higher outside the litterbags than in the litterbags. Particularly for FWD a large part is only reallocated into the $\mathrm{L}$ and $\mathrm{F}$ humus-layer.
As fragmentation increase with decay, determining residence time or decay stage from density is only possible until a decomposition period of 12 years. Then density does not indicates any more the residence time of woody debris. From this moment on volume loss is the parameter which characterizes the decay stage and indicates residence time. The limitation of this parameter is the uncertainty of the initial value which makes it useless in uncontrolled situations.

Only a few studies investigating the decay of beech CWD have been carried out (Schwarze et al. 1999; Kraigher et al. 2002; Schäfer 2002). Comparison with the present study is difficult as definition of decay classes does not match. However, a clear tendency of a rapid initial loss of density of woody debris followed by a phase in which density does not change can be seen.

Residence time in decay classes

On condition that the woody debris supply is constant, the length of time a stem is in a particular state of decay is reflected by the number of stems in different stages of decay (Kuuluvainen et al. 2001). Based on the residence time of woody debris determined for the four decay classes, the number of stems in the later stages of decay should increase. The suggestion of Müller-Using and Bartsch (2003) that the small number of stems in decay class 3 is due to a short decay period is not valid. Moreover this suggests that the stand is just at the beginning of the disintegration and only a small part of the stand development cycle is being observed.

\section{Relevance of the case study}

The decay of woody debris depends on climate (Harmon et al. 1986; Hytteborn and Packham 1987; Hofgaard 1993; Chambers et al. 2000; Mackensen et al. 2003). Mackensen et al. (2003) showed that the decay rate increases significantly only at annual mean temperatures above 12 or $13^{\circ} \mathrm{C}$. Beech forests in Europe grow at sites with lower annual mean temperatures (Bolte et al. 2007). The research area of this study has an annual mean temperature of only $7^{\circ} \mathrm{C}$.

Independent of tree species and climatic zone the annual precipitation has a large influence on the maximum rate of decay (Mackenesen et al. 2003). This however could not be shown in this study (data in Müller-Using 2005). In a comparative study of a number of tree species in North America, Yin (1999) concluded that short term studies often overestimate the importance of site and wood properties for decay rates. The decay model developed by Yin (1999) which uses the parameters tree species, air temperatures, and precipitation in January and July, showed that an increase in temperature of $2^{\circ} \mathrm{C}$ in January and July in the first year 
increases the loss of wood density by $9-55 \%$. Over a period of 100 years however, the rate of decay is increased by only $1-14 \%$. Based on these results we suggest that the results of our study can also be used for a beech woody debris management on similar sites in Central Europe.

Implications for woody debris management

In managed forests, determination of the state of decay of woody debris during normal stand inventories is required for sustainable woody debris management. For beech, this study provides the information needed to estimate the supply of woody debris in different dimensions, as well as volume loss and the residence time in the different stages of decay. However, further investigations are needed in beech forests with different climates and soil types.

In view of the short residence time of the CWD of about 35 years compared to the rotation length (about 100140 years), a continuous temporal and spatial supply of woody debris in managed forests of today would require a repeated, well directed provision of deadwood. An especially big number of xylobiont species has specialized on CWD in the beginning and advanced phases of decay (Kleinevoss et al. 1996; Dorow 2002; Flechtner 2002). The transition time of dead stems in these decay classes adds up to only about 15 years.

At present, ecological target values for woody debris in managed forests do not have a scientific basis, as little is yet known about the influence of volume and quality of woody debris on biodiversity (Böhl and Brändli 2007). The amounts of woody debris postulated for managed forests in Germany and Switzerland differ in dependence on indicator species. Target values of deadwood range from 5 to $10 \mathrm{~m}^{3} \mathrm{ha}^{-1}$ for birds (Ammer 1991; Utschig 1991), about $18 \mathrm{~m}^{3} \mathrm{ha}^{-1}$ for the three-toed woodpecker (Picoides tridactylus) in subalpine spruce forests (Bütler et al. 2004) to about $38-58 \mathrm{~m}^{3} \mathrm{ha}^{-1}$ for saproxylic beetles in deciduous forests (Müller 2005), which 88 amounts to more than a tenth of the volume of mature tree stands.

Acknowledgements We are indebted to Ulrike Westphal, Michaela Knaust, Karl-Heinz Obal, Michael Unger, and Christian Donath for assistance with fieldwork, and for doing the laboratory analyses. We thank Jürgen Bauhus for valuable professional advice and Oda Godbold, and Gina G. Lopez for improving the English. Finally, we thank the anonymous reviewers for their helpful comments on the manuscript. The study was supported by the German Research Foundation (DFG, BA 1263/4-1/2).

\section{References}

Ammer U (1991) Konsequenzen aus den Ergebnissen der Totholzforschung. Forstwiss Centralbl 110:149-157. doi:10.1007/ BF02741249
Ammer U, Utschick H (2004) Folgerungen aus waldökologischen Untersuchungen auf hochproduktiven, nadelholzreichen Standorten für eine an Naturschutzzielen orientierte Waldwirtschaft. Forst Holz 59:119-128

Arthur MA, Fahey TJ (1990) Mass and nutrient content of decaying boles in an Engelmann spruce-subalpine fir forest, Rocky Mountain National Park, Colorado. Can J For Res 20:730-737. doi:10.1139/x90-096

Arthur M, Tritton L, Fahey T (1993) Dead bole mass and nutrients remaining 23 years after clear-felling of a northern hardwood forest. Can J For Res 23:1298-1304. doi:10.1139/x93-166

Assmann T, Drees C, Schröder E, Ssymank A (2007) Mythos Artenarmut-Biodiversität von Buchenwäldern. Naturforsch Landsch 82:401-406

Bartsch N (2000) Element release in beech (Fagus sylvatica L.) forest gaps. Water Air Soil Pollut 122:3-16. doi:10.1023/A: 1005265505479

Bartsch N, Bauhus J, Vor T (2002) Effects of group selection and liming on nutrient cycling in an European beech forest on acidic soil. In: Dohrenbusch A, Bartsch N (eds) Forest developmentsuccession, environmental stress and forest management. Springer, Berlin, pp 109-142

Bauhus J (1994) Stoffumsätze in Lochhieben. Ber. Forschungszentrum Waldökosysteme, Göttingen, A181

Bauhus J, Vor T, Bartsch N, Cowling A (2004) The effects of gaps and liming on forest floor decomposition and soil $\mathrm{C}$ and $\mathrm{N}$ dynamics in a Fagus sylvatica forest. Can J For Res 34:509-518. doi:10.1139/x03-218

Berg A, Ehnstrom B, Hallingback T, Jonsell M, Weslien J (1995) Threat levels and threats to Red-Listed species in Swedish forests. Conserv Biol 9:1629-1633. doi:10.1046/j.1523-1739. 1995.09061629.x

Binot M, Bless R, Boye P, Gruttke H, Pretscher P (1998) Rote Liste gefährdeter Tiere Deutschlands. Schriftenr Landschaft Nat 55:243-249

Bocock KL (1964) Changes in the amount of dry matter, nitrogen, carbon and energy in decomposing woodland leaf litter in relation to the activities of the soil fauna. J Ecol 52:273-284. doi: $10.2307 / 2257595$

Böhl J, Brändli U-B (2007) Dead wood volume assessment in the third Swiss National Forest Inventory: methods and first results. Eur J For Res 126:449-457. doi:10.1007/s10342-007-0169-3

Bolte A, Czajkowski T, Komap T (2007) The north-eastern distribution range of Europaean beech-a review. Forestry 80:413429. doi:10.1093/forestry/cpm028

Bütler R, Angelstam P, Schlaepfer R (2004) Quantitative snag targets for the three-toed woodpecker Picoides tridactylus. Ecol Bull 51:219-232

Chambers J, Higuchi N, Schimel J, Ferreira L, Melack J (2000) Decomposition and carbon cycling of dead trees in tropical forests of the central Amazon. Oecologia 122:380-388. doi: $10.1007 / \mathrm{s} 004420050044$

Christensen O (1977) Estimation of standing crop and turnover of dead wood in a Danish oak forest. Oikos 28:177-186. doi: $10.2307 / 3543969$

Christensen O (1984) The states of decay of woody litter determined by relative density. Oikos 42:211-219. doi:10.2307/3544795

Christensen M, Hahn K, Mountford EP, Ódor P, Standovár T, Rozenbergar D, Diaci J, Wijdeven S, Meyer P, Winter S, Vrska $\mathrm{T}$ (2005) Dead wood in European beech (Fagus sylvatica) forest reserves. For Ecol Manage 210:267-282

Czajkowski T, Kompa T, Bolte A (2006) Zur Verbreitungsgrenze der Buche (Fagus sylvatica L.) im nordöstlichen Mitteleuropa. Forstarchiv 77:203-216

Dorow W (2002) Zoologische Untersuchungen auf der Sturmwurffläche. Mitt Hess Landesforstverw 38:70-115 
Edmonds RL, Eglitis A (1989) The role of Douglas-fir beetle and wood borers in the decomposition of and nutrient release from Douglas-fir logs. Can J Res 19:853-859. doi:10.1139/x89-130

Ellenberg H, Mayer R, Schauermann J (1986) ÖkosystemforschungErgebnisse des Solling-Projektes. Ulmer, Stuttgart

Flechtner G (2002) Die Rolle der Käfer beim Abbau von BuchenTotholz auf der Sturmwurffläche. Mitt Hess Landesforstverw 38:123-145

Franc N, Götmark F, Økland B, Nordén B, Paltto H (2007) Factors and scales potentially important for saproxylic beetles in temperate mixed oak forest. Biol Conserv 135:86-98. doi: 10.1016/j.biocon.2006.09.021

Frangi J, Richter L, Barrera M, Aloggia M (1997) Decomposition of Nothofagus fallen dead wood in forests of Tierra del Fuego, Argentina. Can J For Res 27:1095-1102. doi:10.1139/cjfr-27-71095

FSC (Forest Stewardship Council Arbeitsgruppe Deutschland e.V.) (2008) Deutscher FSC-Standard. www.fsc-deutschland.de/ infocenter/instand.htm

Grier CC (1978) A Tsuga heterophylla-Picea sitchensis ecosystem of coastal Oregon: decomposition and nutrient balances of fallen logs. Can J For Res 8:198-206

Harmon M, Hua C (1991) Coarse dead wood dynamics in two oldgrowth ecosystems. Biomed Sci 41:604-610

Harmon M, Franklin J, Swanson F, Sollins P, Gregory S, Lattin J, Anderson N, Cline S, Aumen N, Sedell J, Lienkaemper G, Cromack K, Cummins J, Cummins K (1986) Ecology of coarse dead wood in Temperate Ecosystems. Adv Ecol Res 15:133302. doi:10.1016/S0065-2504(08)60121-X

Harmon ME, Cromack K, Smith BG (1987) Coarse dead wood in mixed-conifer forests, Sequoia National Park, California. Can J For Res 17:1265-1272. doi:10.1139/x87-196

Harmon M, Krankina O, Sexton J (2000) Decomposition vectors: a new approach to estimating woody detritus decomposition dynamics. Can J For Res 30:76-84. doi:10.1139/cjfr-30-1-76

Hofgaard A (1993) 50 Years of change in a Swedish boreal oldgrowth Picea abies forest. J Veg Sci 4:773-782. doi:10.2307/ 3235614

Hövemeyer K, Schauermann J (2003) Succession of diptera on dead beech wood-a 10-year study. Pedobiologia (Jena) 47:61-75. doi:10.1078/0031-4056-00170

Hytteborn H, Packham J (1987) Decay rate of Picea abies logs and the storm gap theory: a re-examination of Serander Plot III, Fiby Urskog, Central Sweden. Arboric J 11:299-311

Jenny H, Gessel SP, Bingham FT (1949) Comparative study of decomposition rates of organic matter in temperate and tropical regions. Soil Sci 68:419-432. doi:10.1097/00010694-19491200000001

Kleinevoss K, Topp W, Bohac J (1996) Buchentotholz im Wirtschaftswald als Lebensraum für xylobionte Käfer. Z Okol Naturforsch 5:85-95

Kraigher H, Jurc D, Kalan P, Kutnar L, Levanic T, Rupel M, Smolej I (2002) Beech coarse dead wood characteristics in two virgin forest reserves in southern Slovenia. Zb Gozd Lesar 69:91-134

Kuehne C, Donath C, Müler-Using S, Bartsch N (2008) Nutrient fluxes via leaching from coarse woody debris in a Fagus sylvatica forest in the Solling Mountains, Germany. Can J For Res 38:2405-2413. doi:10.1139/X08-088

Kuuluvainen T, Syrjänen K, Kalliola R (2001) Logs in a pristine Picea abies forest: occurrence, decay stage distribution and spatial pattern. Ecol Bull 49:105-113

Laiho R, Prescott C (2004) Decay and nutrient dynamics of coarse dead wood in northern coniferous forests: a synthesis. Can J For Res 34:763-777. doi:10.1139/x03-241

Mackensen J, Bauhus J, Webber E (2003) Decomposition rates of coarse dead wood-a review with particular emphasis on
Australian tree species. Aust $\mathrm{J}$ Bot 51:27-37. doi: 10.1071/BT02014

MacMillan PC (1988) Decomposition of coarse woody debris in an old-growth Indiana forest. Can J For Res 18:1353-1362. doi: $10.1139 / x 88-212$

Marra JL, Edmonds RL (1996) Coarse woody debris and soil respiration in a clearcut on the Olympic peninsula, Washington, USA. Can J For Res 26:1337-1345. doi:10.1139/x26-149

Maser C, Tarrant R, Trappe J, Franklin J (1988) From the forest to the sea-a story of fallen trees. USDA Forest Service Pacific Northwest Forest Range Experiment Station General Technical Report PNW-229, Portland

Means J, Cromack KJ, MacMillan P (1985) Comparison of decomposition models using wood density of Douglas-fir logs. Can J For Res 15:1092-1098. doi:10.1139/x85-178

Meyer P (1999) Totholzuntersuchungen in Nordwestdeutschen Naturwäldern. Methodik und erste Ergebnisse. Forstwiss Centralbl 118:167-180. doi:10.1007/BF02768985

Müller J (2005) Waldstrukturen als Steuergröße für Artengemeinschaften in kollinen bis submontanen Buchenwäldern. Dissertation, Technical University, Munich

Müller-Using S, Bartsch N (2003) Totholzdynamik eines Buchenbestandes (Fagus silvatica L.) im Solling-Nachlieferung, Ursache und Zersetzung von Totholz. Allg Forst Jagdz 174:122-130

Müller-Using S (2005) Totholzdynamik eines Buchenbestandes im Solling. Ber. Forschungszentrum Waldökosysteme, Göttingen, p A193

Müller-Using S, Bartsch N (2008) Storage and fluxes of carbon in coarse woody debris of Fagus sylvatica L. Forstarchiv 79:164171

Mund M (2004) Carbon pools of European beech forests (Fagus sylvatica) under different silvicultural management. Ber Forschungszentrum Waldökosysteme, Göttingen, p A189

Nagel J (1999) Volumenermittlung von stehendem und liegendem Totholz. In: Buchennaturwald-Reservate NUA Seminarbericht, vol 4. pp 311-313

PEFC (Pan European Forest Certification Council) (2008) Technical documentation. www.pefc.org/internet/html/documentation/4 1311_400.htm

Pillsbury N, Reimer JL (1997) Proceedings of a symposium on oak woodlands: ecology, management, and urban interface issues, March 19-22. USDA Forest Service General Technical Report PSW-GTR-160, Obispo

Pommerening A, Murphy ST (2004) A review of the history, definitions and methods of continuous cover forestry with special attention to afforestation and restocking. Forestry 77:27-44. doi: 10.1093/forestry/77.1.27

Rademacher P (2002) Ermittlung der Ernährungssituation, der Biomasseproduktion und der Nährelementakkumulation mit Hilfe von Inventarverfahren sowie Quantifizierung der Entzugsgrößen auf Umtriebsebene in forstlich genutzten Beständen. Habilitationsschrift University, Göttingen

Rademacher C, Winter S (2003) Totholz im Buchen-Urwald: Generische Vorhersagen des Simulationsmodells BEFORECWD zur Menge, räumlichen Verteilung und Verfügbarkeit. Forstwiss Centralbl 122:337-357. doi:10.1007/s10342-003$0002-6$

Ranius T, Fahrig L (2006) Targets of maintenance of dead wood for biodiversity conservation on extinction thresholds. Scand J For Res 21:201-208. doi:10.1080/02827580600688269

Ranius T, Kindvall O, Kruys N, Jonsson B (2003) Modelling dead wood in Norway spruce stands subject to different management regimes. For Ecol Manage 182:13-29

Ranius T, Jonsson B, Kruys N (2004) Modelling dead wood in Fennoscandian old-growth forests dominated by Norway spruce. Can J For Res 34:1025-1034. doi:10.1139/x03-271 
Röhrig E (1991) Totholz im Wald. Forstl Umsch 34:259-270

Schaefer M, Schauermann J (1990) The soil fauna of beech forestscomparison between a mull and a moder soil. Pedobiologia (Jena) 34:299-314

Schäfer M (2002) Zersetzung der sturmgeworfenen Buchenstämme im Naturwaldreservat Weiherskopf seit 1990. Mitt Hess Landesforstverw 38:49-60

Scherzinger W (1996) Naturschutz im Wald. Eugen Ulmer, Stuttgart

Scheu S, Falca M (2000) The soil food web of two beech forests (Fagus sylvatica) of contrasting humus type: stable isotope analysis of a macro- and a mesofauna-dominated community. Oecologica 123:285-286. doi:10.1007/s004420051015

Schuck A, Meyer P, Menke N, Lier M, Lindner M (2004) Forest biodiversity indicator: dead wood-a proposed approach towards operationalising the MCPFE indicator. In: Marchetti $M$ (ed) Monitoring and indicators of forest biodiversity in Europe-from ideas to operationality. EFI Proceedings No 51, Göttingen, pp 49-77

Schwarze FW, Engels J, Mattheck C (1999) Holzzersetzende Pilze in Bäumen. Strategien der Holzzersetzung. Rombach Ökologie 5. Rombach, Freiburg
Sollins P (1982) Input and decay of coarse dead wood in coniferous stands in western Oregon and Washington. Can J For Res 12:1828. doi:10.1139/x82-003

Sollins P, Cline S, Verhoeven T, Sachs D, Spycher G (1987) Patterns of $\log$ decay in old-growth Douglas fir forests. Can J For Res 17:1585-1595. doi:10.1139/x87-243

Utschig H (1991) Beziehungen zwischen Totholzreichtum und Vogelwelt in Wirtschaftwäldern. Forstwiss Centralbl 110:135148. doi:10.1007/BF02741248

von Oheimb G, Westphal C, Härdtle W (2007) Diversity and spatiotemporal dynamics of dead wood in a temperate near-natural beech forest (Fagus sylvatica). Eur J For Res 126:359-370. doi: 10.1007/s10342-006-0152-4

Yatskov M, Harmon ME, Krankina ON (2003) A chronosequence of wood decomposition in the boreal forests of Russia. Can J For Res 33:1211-1226. doi:10.1139/x03-033

Yin X (1999) The decay of forest dead wood: numerical modeling and implications based on some 300 data cases from North America. Oecologia 121:81-98. doi:10.1007/s004420050909 